\title{
Comparison Between Y- and S-Shaped Incisions for Open Reduction and Hook-Plate Fixation of the Mallet Finger
}

\section{Gökçer UZER, Fatih YILDIZ, Mehmet KAPICIOĞLU, Mehmet ELMADAĞ, Deniz KARA, Kerem BILSEI} Department of Orthopedics and Traumatology, Bezmialem Vakıf University School of Medicine, İstanbul, Turkey

\section{ABSTRACT}

Objective: This study evaluates the results of open reduction and hook-plate fixation in the treatment of osseous mallet finger and compares S- and Y-shaped incisions used for the approach.

Methods: Twenty-eight patients treated for osseous mallet finger using open reduction and hook-plate fixation were divided into two groups according to their incisions types (group I: S-shaped, $\mathrm{n}=18$; and group II: Y-shaped, $\mathrm{n}=10$ ). Functional results at the first year of follow-up and complications were evaluated.

Results: All fractures healed. In group I, all patients had excellent results; in group II, nine patients had excellent results, and one patient had fair results. The numbers of complications were two in group I and six in group II.

Conclusion: Hook-plate fixation is a successful treatment method for osseous mallet finger. The rate of complications can be decreased using an "S-shaped" incision with this technique. However, patients should be informed about possible skin problems and nail deformities.

Keywords: Mallet, hook-plate, S-incision, Y-incision

\section{Introduction}

Mallet finger is known as extension loss at the distal interphalangeal joint (DIP). It is called soft-tissue mallet finger if it is caused due to extensor tendon rupture at zone I and osseous mallet finger if it is caused by bony avulsion of the extensor tendon. Osseous mallet finger is usually seen in young and middle-aged male patients and in approximately $74 \%$ of cases, the dominant hand is affected $(1,2)$.

The most frequent mechanism of the injury is sudden flexion at the DIP caused by force on the longitudinal axis of the finger (3). Splint usage is believed to be effective in the treatment of minimally displaced or soft-tissue mallet finger; however, if there is more than $3 \mathrm{~mm}$ excursion of the extensor tendon, extensor lag or bump formation at the dorsal part of the finger can be seen as complications $(1,4-7)$. Surgical treatment is recommended if there is volar subluxation, mostly due to the bony fragment including $>50 \%$ of the joint surface, dorsal bony fragment which include $>30 \%$ of the joint surface or $>3 \mathrm{~mm}$ of displacement, failed previous treatment, and open injuries (2, 8-10). The most frequent sequels of the neglected mallet finger are extensor lag, a prominent bump on the dorsal surface of the finger, and swan neck deformity (2).

There are several surgical techniques in the treatment of mallet finger such as repair using micro-screws, Kirshner wire pinning, and hook-plate, external fixator or button application (11-17). Surgical treatment has advantages in terms of early postoperative mobilization of fingers and early return to work. However, it may have some disadvantages such as nail deformities, paronychia, osteomyelitis, skin necrosis, and joint contractures (18).

This retrospective study compared clinical and radiological results of S-shaped and Y-shaped incisions in the treatment of osseous mallet finger using open reduction and hook-plate fixation.

\begin{tabular}{|c|c|c|}
\hline $\begin{array}{l}\text { Address for Correspondence: Fatih YILDIZ; Bezmialem Vakıf Üniversitesi Tıp Fakültesi, Ortopedi ve Travmatoloji, } \\
\text { İstanbul, Türkiye E-mail: yildizfatih@hotmail.com }\end{array}$ & $\begin{array}{l}\text { Receive } \\
\text { Accepted }\end{array}$ & $\begin{array}{l}: 09.03 .2016 \\
: 25.04 .2016\end{array}$ \\
\hline
\end{tabular}




\section{Methods}

This study was performed according to the declaration of Helsinki and institutional review board approval was obtained. Between January 2012 and September 2014, 28 patients (20 males and 8 females) who were admitted to our emergency department, diagnosed with osseous mallet finger, and surgically treated using open reduction and hook-plate fixation were included in the study. Patient charts and hospital's digital data were retrospectively reviewed. The patients were divided into two groups according to their incision types. An S-shaped incision (group I) was used in 18 patients (12 males and 6 females) and a Y-shaped incision (group II) was used in 10 (8 males and 2 females) patients (Table 1). The mean ages of the patients were 29 (range, 12-64) years in group I and 28 (range, 15-36) years in group II. In group I, fractures were on the right hand in 12 patients and on the left hand in six patients, whereas in group II, fractures were on the right hand and left hand in five patients each. None of the fractures were open fractures.

The fractures were classified according to Wehbe and Schneider (1). All patients who had volar subluxation of the distal phalanx, dorsal fragment including $>30 \%$ of the joint, or displacement of $>3 \mathrm{~mm}$ were offered surgical treatment. Surgeries were performed under digital block anesthesia using custom-made finger tourniquet by two surgeons via S-shaped or Y-shaped incisions (Figure 1,2). After open reduction of the fractures, fixations were achieved using hook-plates (Medartis, Basel, Switzerland).

All operated fingers were immobilized using single finger splints and passive range of motions (ROM) of the DIP joints were started on postoperative day 2. Passive ROM exercises were performed for 10 min each day for 2 weeks. Between 2 and 6 weeks, active flexion and passive extension of the DIP joint was applied. The splint remained fixed except during sleep and physical therapy until the end of 6 weeks.

Antero-posterior and lateral radiographs were obtained at 3 and 6 weeks and 3 months (Figure 3, 4). Functional evaluations were performed after the first year of follow-up using Crawford's criteria (19). Complications were also recorded.

\section{Statistical analysis}

Flexion and extension ranges of the groups were compared using Mann-Whitney $U$ test and the rate of complications were compared using chi-square test. $\mathrm{P}$ values of $<0.05$ was accepted as statistically significant.

\section{Results}

All fractures healed within 2 months after the surgeries. According to Crawford's criteria, in group I, seven patients had excellent results and 11 patients had good results; in group II, four patients had excellent results, five patients had good results, and one patient had fair results (Table 2). The mean extension loss was $6.38^{\circ} \mathrm{C}\left(\right.$ range; $\left.0^{\circ} \mathrm{C}-10^{\circ} \mathrm{C}\right)$ in

\begin{tabular}{|c|c|c|c|}
\hline & & $\begin{array}{l}\text { Group I } \\
(n=18)\end{array}$ & $\begin{array}{c}\text { Group II } \\
(n=10)\end{array}$ \\
\hline \multirow[t]{4}{*}{$\begin{array}{l}\text { Localization } \\
\text { of the fracture }\end{array}$} & Index & 2 & 1 \\
\hline & Middle & 5 & 4 \\
\hline & Ring & 4 & 2 \\
\hline & Little & 7 & 3 \\
\hline \multirow[t]{3}{*}{ Mechanism of trauma } & Sports injury & 7 & 3 \\
\hline & Direct trauma & 11 & 4 \\
\hline & Fall-down & - & 3 \\
\hline \multirow[t]{3}{*}{$\begin{array}{l}\text { Classification } \\
\text { of the fractures } \\
\text { (Wehbe-Schneider) }\end{array}$} & Type 1B & 12 & 6 \\
\hline & Type 2B & 2 & 2 \\
\hline & Type 3B & 4 & 2 \\
\hline
\end{tabular}

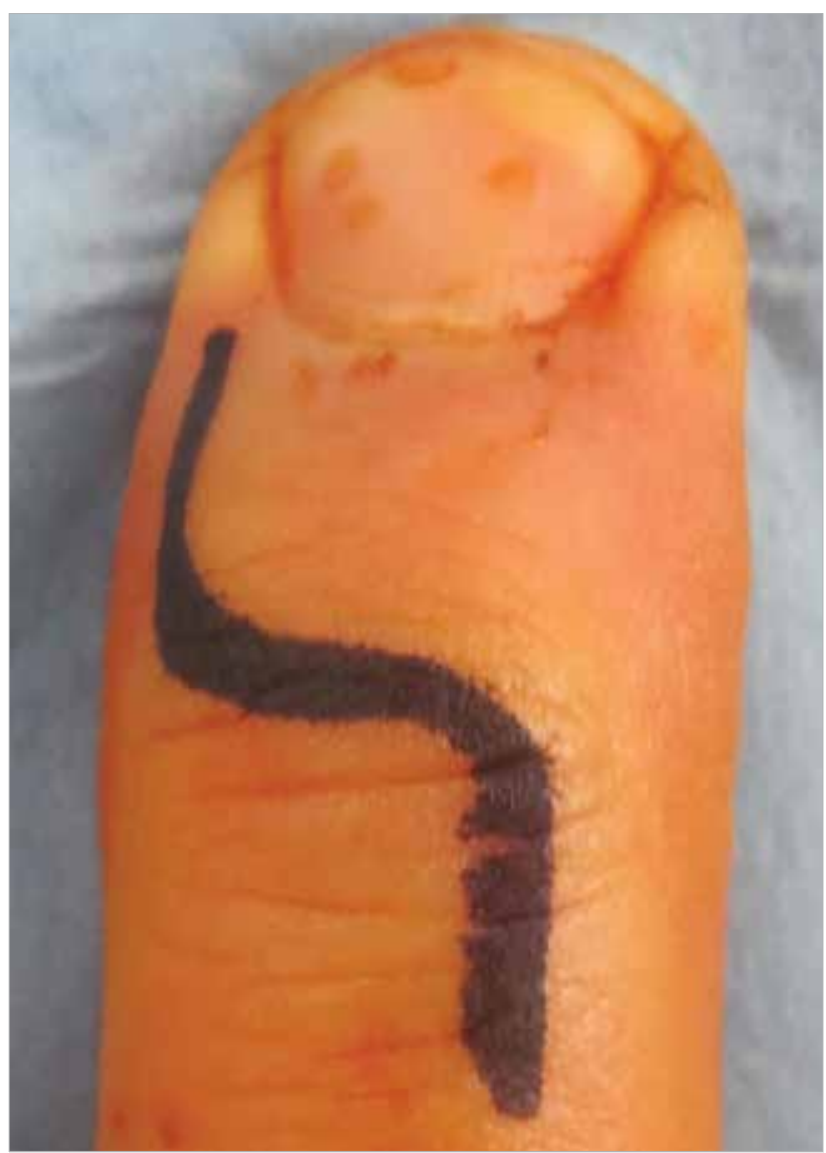

Figure 1. S-shaped incision

group I and $6.5^{\circ}$ (range; $\left.0^{\circ} \mathrm{C}-30^{\circ} \mathrm{C}\right)$ in group II $(\mathrm{p}=0.727)$. The mean range of flexion was $61.1^{\circ} \mathrm{C}$ (range, $50^{\circ} \mathrm{C}-80^{\circ} \mathrm{C}$ ) in group I and $60.5^{\circ} \mathrm{C}$ (range; $50^{\circ} \mathrm{C}-75^{\circ} \mathrm{C}$ ) in group II $(\mathrm{p}=0.546)$.

Total numbers of complications were eight in five patients. Osteomyelitis or DIP joint arthritis was not seen in any pa- 


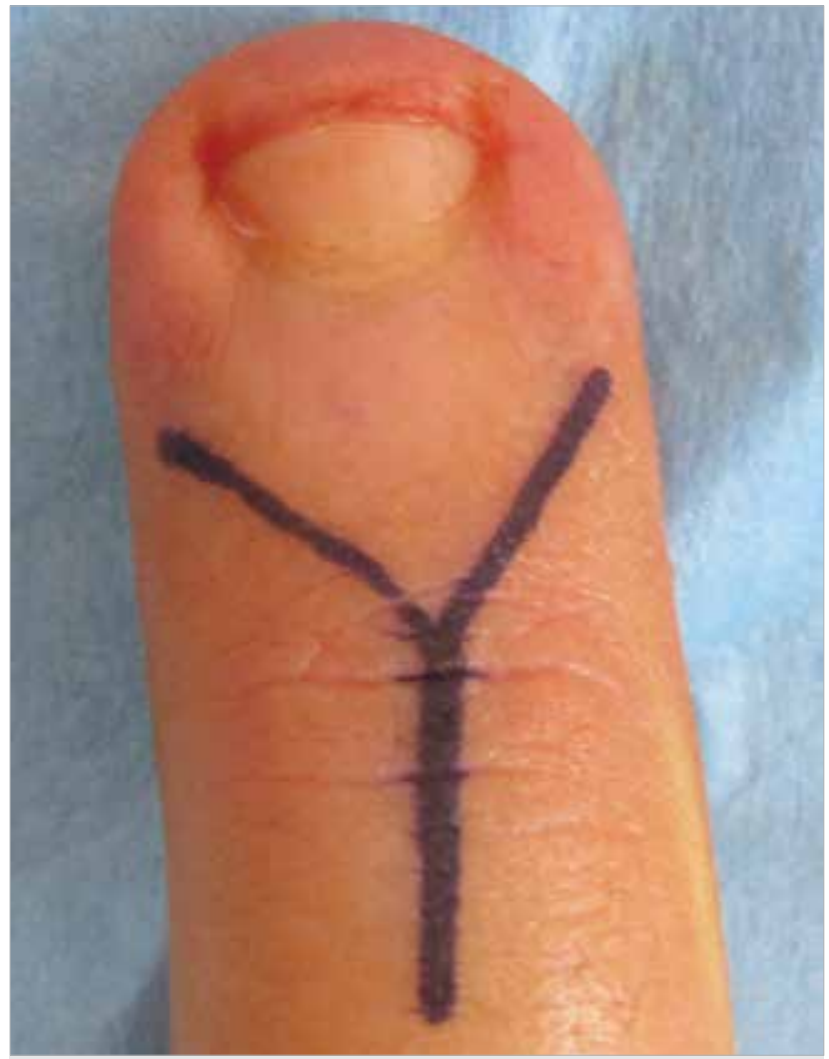

Figure 2. Y-shaped incision

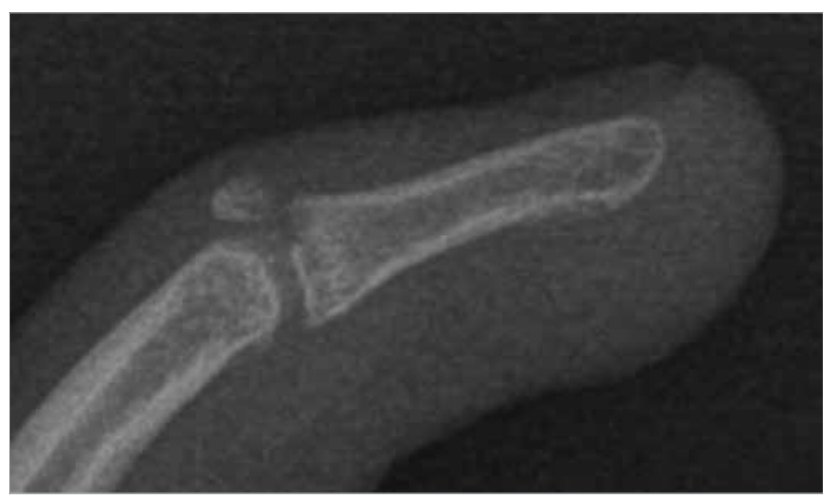

Figure 3. Lateral X-ray show osseous mallet finger requiring surgical treatment

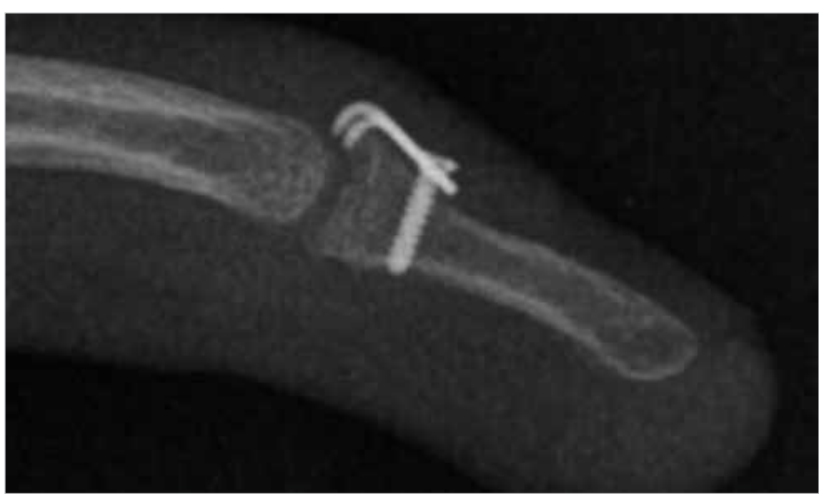

Figure 4. Lateral X-ray taken after 6 months of followup shows union
Table 2. Functional results and complications

\begin{tabular}{|c|c|c|}
\hline & Group I & Group II \\
\hline \multirow[t]{3}{*}{$\begin{array}{l}\text { Functional results } \\
\text { (Crawford's criteria) }\end{array}$} & Excellent $(n=7)$ & Excellent $(n=4)$ \\
\hline & Good $(n=11)$ & Good $(n=5)$ \\
\hline & & Poor $(n=1)$ \\
\hline \multirow[t]{4}{*}{ Complications } & $\begin{array}{l}\text { Nail deformity } \\
\qquad(n=2)\end{array}$ & $\begin{array}{l}\text { Nail deformity } \\
\qquad(n=3)\end{array}$ \\
\hline & & $\begin{array}{l}\text { Skin necrosis } \\
\quad(n=1)\end{array}$ \\
\hline & & $\begin{array}{l}\text { Implant exposition } \\
\qquad(n=1)\end{array}$ \\
\hline & & Paronychia $(n=1)$ \\
\hline
\end{tabular}

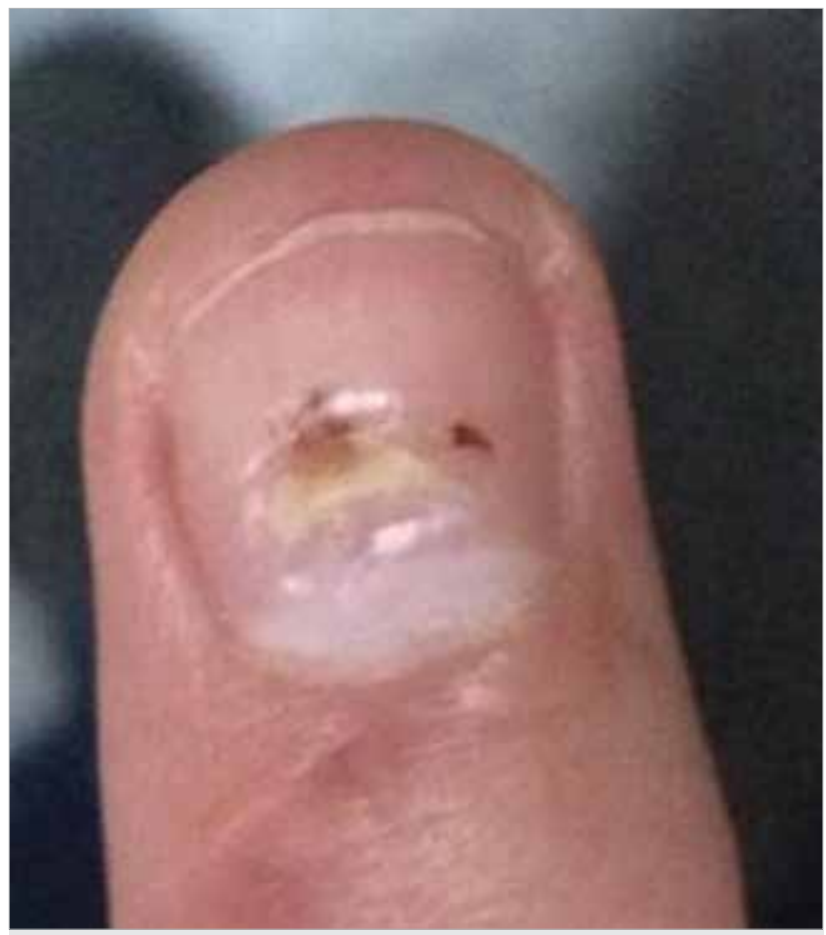

Figure 5. Nail deformity of a patient from the S-shaped incision group after 3 months of follow-up

tient during the follow-up period. In group I, the only complication was nail deformities in two patients (Figure 5). In group II, nail deformities $(n=3)$, paronychia $(n=1)$ that was treated using antibiotics, skin necrosis $(n=1)$ requiring debridement and implant removal (Figure 6), and implant exposition $(\mathrm{n}=1)$ after 8 weeks of follow-up (Figure 7) were recorded as complications. Due to these complications, plates were removed in six patients for cosmetic reasons or nail deformity $(\mathrm{n}=4)$, implant exposition $(\mathrm{n}=1)$, and skin necrosis $(\mathrm{n}=1)$. The patient with skin necrosis was treated using an extension brace after implant removal, and the fracture was healed with malunion with approximately $30^{\circ}$ of extension loss. During the follow-up, nail deformities had improved. 


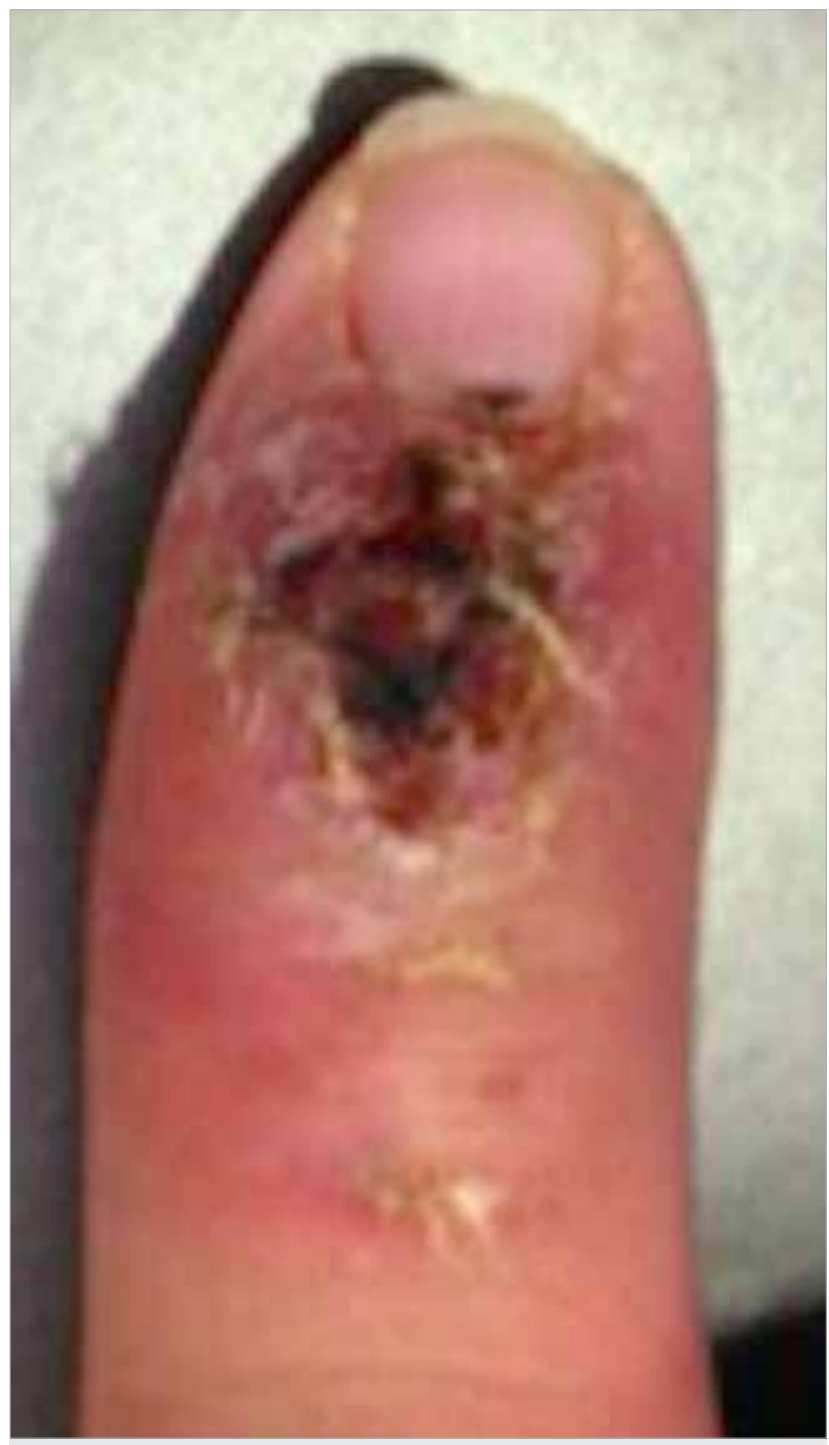

Figure 6. Skin necrosis after the surgery with Y-shaped incision

\section{Discussion}

Open or closed techniques in mallet finger surgeries aim to obtain functional, pain-free DIP joints without extension lag. The most frequently used techniques of the closed reduction groups include $\mathrm{K}$-wire fixation. In a study regarding $\mathrm{K}$-wire fixation of the osseous mallet finger by Lubahn et al. (20) the mean range of DIP joint flexion was $55^{\circ} \mathrm{C}$ and up to $20^{\circ} \mathrm{C}$ of extension lag was reported. Pegoli et al. (21) found that 13 of their 65 patients $(20 \%)$ resulted with fair results due to inappropriate reduction.

In a study on open reduction and $\mathrm{K}$-wire fixation by Fritz et al. (22), 21 out of the 24 patients $(87.5 \%)$ had $<10^{\circ} \mathrm{C}$ extension lag; however, six patients (25\%) had narrowing of DIP joint space. Zhang et al. (15) stated that although excellent results were obtained in 52 of 64 patients in whom K-wire stabilization and pull out wire technique were performed, they observed dissatisfaction in many patients due to external wires during 6 weeks. In the current study, joint space

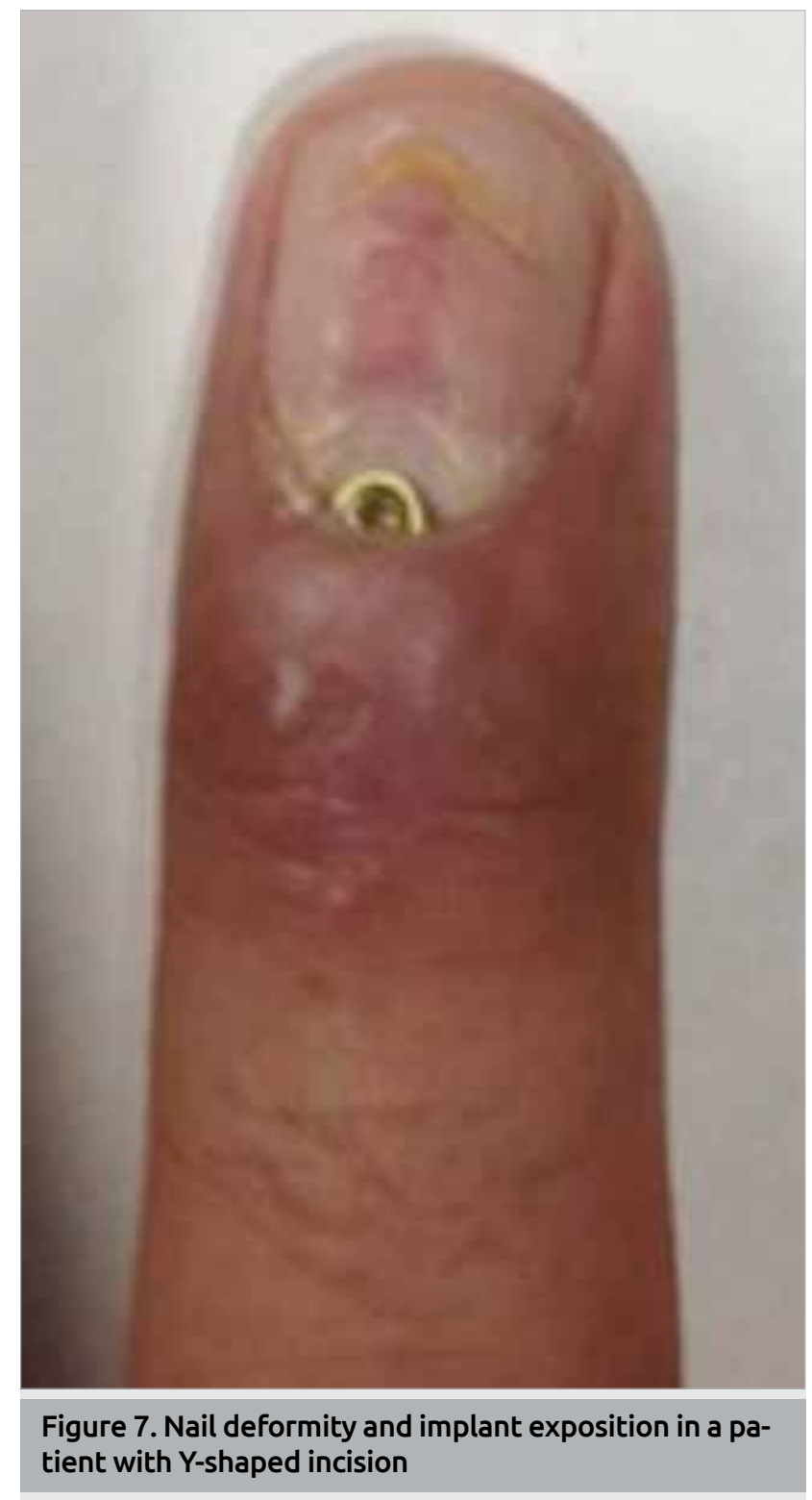

narrowing or arthritis was not seen in any patient, and the mean flexion ranges were $61.1^{\circ} \mathrm{C}$ in group $\mathrm{I}$ and $60.5^{\circ} \mathrm{C}$ in group II. Full extension in 11 patients, up to $10^{\circ} \mathrm{C}$ of extension deficit in 16 patients, and $30^{\circ}$ extension deficit in one patient was seen.

In the treatment of the mallet finger using hook-plate, Teoh and Lee used their modified hook-plate and reported successful results in all patients (13). Later, Szaly et al. (23) reported excellent results in 35 of 59 patients and good results in 16 patients. In our series, excellent results with full extension were obtained in 11 of 28 patients and good results in 16 patients and fair results in one patient, according to Crawford's criteria. In total, 27 of 28 patients had $<10^{\circ} \mathrm{C}$ extension loss.

Complication rate of the surgical treatment varies in the literature (5\%-63\%) and osteomyelitis, extension lag, implant failure, nail deformities, skin necrosis, loss of reduction, pin tract infection, incongruent joint, and osteoarthritis are re- 
ported as complications $(24,25)$. Lange et al. recommends obtaining a congruent joint without subluxation (26). In some studies, anatomical reduction and internal fixation of the displaced fragment is recommended to avoid joint stiffness and deformities $(3,9)$. Wehbe et al. (1) reveals that insufficient or inappropriate treatment of the mallet finger may result in early osteoarthritis, limitation in extension, and swan neck deformity. Stern et al. (27) reported that the highest complication rate was seen in K-wire fixation between different surgical techniques.

After open reduction, nail deformities can develop due to close relation between nail germinal matrix and fracture line. In a study comparing extension block and open reduction and internal fixation using mini-screw, nail deformities were seen in two patients in extension block pinning group (28). Szaly et al. (23) reported nail deformities in 7 of 59 patients $(11.9 \%)$. This rate was $17.8 \%$ (5 of 28 patients) in our study.

Szalay et al. (23) used Y-shaped, S-shaped, and H-shaped incisions and reported no inflammation or surgical site healing problem. In our study, although similar functional results and ROM of the DIP joints were found between the groups, the number of complications was three times higher in the Yshaped incision group. In this group, infection, skin necrosis, and implant exposition increased the complication rate. In our patient, skin necrosis was probably related to malposition of the plate.

\section{Conclusion}

According to the results of our study and the literature, we conclude that in the treatment of osseous mallet finger, open reduction and internal fixation using a hook-plate is a reproducible, successful, and alternative method that allows rigid fixation and early mobilization. The rate of complications can be decreased using an "S-shaped" incision during the exposure. However, patients should be informed about possible skin problems and nail deformities.

Ethics Committee Approval: Authors declared that the research was conducted according to the principles of the World Medical Association Declaration of Helsinki "Ethical Principles for Medical Research Involving Human Subjects", (amended in October 2013).

Informed Consent: Written informed consent was not received due to the retrospective nature of this study.

Peer-review: Externally peer-reviewed.

Author Contributions: Concept - G.U., F.Y., M.K., M.E., D.K., K.B.; Design - G.U., F.Y., M.K., M.E., D.K., K.B.; Supervision - G.U., F.Y., M.K., M.E., D.K., K.B.; Funding - G.U., F.Y.; Materials - M.E., M.K.; Data Collection and/or Processing - M.E., M.K.; Analysis and/or Interpretation - K.B., D.K.; Literature Review - G.U.; Writing - G.U., F.Y.; Critical Review - F.Y.

Conflict of Interest: No conflict of interest was declared by the authors.

Financial Disclosure: The authors declared that this study has received no financial support.

\section{References}

1. Wehbe MA, Schneider LH. Mallet fractures. J Bone Joint Surg Am 1984; 66: 658-69. [CrossRef]

2. Alla SR, Deal ND, Dempsey IJ. Current concepts: mallet finger. Hand (NY) 2014; 9: 138-44. [CrossRef]

3. Stark HH, Boyes JH, Wilson JN. Mallet finger. J Bone Joint Surg Am 1962; 44-A: 1061-8. [CrossRef]

4. Jablecki J, Syrko M. Zone 1 extensor tendon lesions: current treatment methods and a review of literature. Ortop Traumatol Rehabil 2007; 9: 52-62.

5. Cheung JP, Fung B, Ip WY. Review on mallet finger treatment. Hand Surg 2012; 17: 439-47. [CrossRef]

6. Niechajev IA. Conservative and operative treatment of mallet finger. Plast Reconstr Surg 1985; 76: 580-5. [CrossRef]

7. Bendre AA, Hartigan BJ, Kalainov DM. Mallet finger. J Am Acad Orthop Surg. 2005; 13: 336-44. [CrossRef]

8. Husain SN, Dietz JF, Kalainov DM, Lautenschlager EP. A biomechanical study of distal interphalangeal joint subluxation after mallet fracture injury. J Hand Surg Am 2008; 33: 26-30. [CrossRef]

9. Hamas RS, Horrell ED, Pierret GP. Treatment of mallet finger due to intra-articular fracture of the distal phalanx. J Hand Surg Am 1978; 3: 361-3. [CrossRef]

10. Damron TA, Engber WD. Surgical treatment of mallet finger fractures by tension band technique. Clin Orthop Relat Res 1994: 133-40. [CrossRef]

11. Kronlage SC, Faust D. Open reduction and screw fixation of mallet fractures. J Hand Surg Br 2004; 29: 135-8. [CrossRef]

12. Lee YH, Kim JY, Chung MS, Baek GH, Gong HS, Lee SK. Two extension block Kirschner wire technique for mallet finger fractures. J Bone Joint Surg Br 2009; 91: 1478-81. [CrossRef]

13. Teoh LC, Lee JY. Mallet fractures: a novel approach to internal fixation using a hook plate. J Hand Surg Eur Vol 2007; 32: 24-30. [CrossRef]

14. Kaleli T, Ozturk C, Ersozlu S. External fixation for surgical treatment of a mallet finger. J Hand Surg Br 2003; 28: 228-30. [CrossRef]

15. Zhang X, Meng H, Shao X, Wen S, Zhu H, Mi X. Pull-out wire fixation for acute mallet finger fractures with k-wire stabilization of the distal interphalangeal joint. J Hand Surg Am 2010; 35:1864-9. [CrossRef]

16. Rha E, Lee M, Lee J, Moon S, Rhie J, Oh D. Treatment of mallet fracture using a percutaneous fixation technique with an 18-gauge needle. Acta Orthop Belg 2015; 81: 296-302.

17. Acar MA, Guzel Y, Gulec A, Uzer G, Elmadag M. Clinical comparison of hook plate fixation versus extension block pinning for bony mallet finger: a retrospective comparison study. J Hand Surg Eur Vol 2015; 40: 832-9. [CrossRef]

18. King HJ, Shin SJ, Kang ES. Complications of operative treatment for mallet fractures of the distal phalanx. J Hand Surg Br 2001; 26: 28-31. [CrossRef]

19. Crawford GP. The molded polythene splint for mallet finger deformities. J Hand Surg Am 1984; 9: 231-7. [CrossRef]

20. Lubahn JD. Mallet finger fractures: a comparison of open and closed technique. J Hand Surg Am 1989; 14: 394-6. [CrossRef]

21. Pegoli L, Toh S, Arai K, Fukuda A, Nishikawa S, Vallejo IG. The Ishiguro extension block technique for the treatment of mallet finger fracture: indications and clinical results. J Hand Surg Br 2003; 28: 15-7. [CrossRef]

22. Fritz D, Lutz M, Arora R, Gabl M, Wambacher M, Pechlaner S. Delayed single Kirschner wire compression technique for mallet fracture. J Hand Surg Br 2005; 30: 180-4. [CrossRef] 
23. Szalay G, Schleicher I, Kraus R, Pavlidis T, Schnettler R. [Operative treatment of the mallet fracture using a hook plate]. Handchir Mikrochir Plast Chir 2011; 43: 46-53. [CrossRef]

24. Auchincloss JM. Mallet-finger injuries: a prospective, controlled trial of internal and external splintage. Hand 1982; 14: 168-73. [CrossRef]

25. Nakamura K, Nanjyo B. Reassessment of surgery for mallet finger. Plast Reconstr Surg 1994; 93: 141-9; discussion 50-1. [CrossRef]
26. Lange RH, Engber WD. Hyperextension mallet finger. Orthopedics. 1983; 6: 1426-31.

27. Stern PJ, Kastrup JJ. Complications and prognosis of treatment of mallet finger. J Hand Surg Am 1988; 13: 329-34. [CrossRef]

28. Lucchina S, Badia A, Dornean V, Fusetti C. Unstable mallet fractures: a comparison between three different techniques in a multicenter study. Chin J Traumatol 2010; 13: 195-200. 